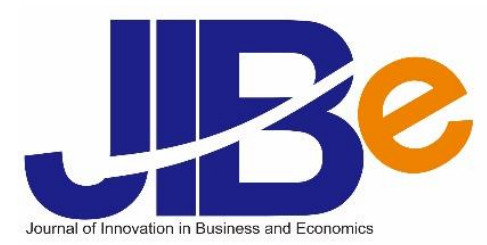

\title{
Do Islamic social entrepreneurship moderate Islamic leadership and emotional intelligence? Evidence from micro and small enterprises fostered by 'Aisyiyah
} Nurul Asfiah ${ }^{1}$

\author{
Management Department, Faculty of Economic and Business, \\ Universitas Muhammadiyah Malang. Indonesia ${ }^{l}$
}

DOI: https://doi.org/10.22219/jibe.v5i01.16221

\begin{abstract}
This study aims to understand Islamic social entrepreneurship in moderating the influence of Islamic leadership and emotional intelligence to improve Micro and Small Enterprises (SMEs). Another objective of this study is to determine the effect of Islamic leadership, emotional intelligence, and Islamic social entrepreneurship on business performance. This research is quantitative research, whose population is a group of SMEs fostered by 'Aisyiyah East Java so that 150 respondents were determined. This amount is calculated by non-probability sampling and judgmental sampling techniques based on the researcher's considerations. The sample was decided to be used due to existing uncertain population, and the collection of questionnaires using Google forms. All variables are valid and reliable; data analysis using path analysis technique with Smart PLS 3.0 software found a direct and indirect effect of Islamic social entrepreneurship variable on SME business performance. This analysis also shows that Islamic leadership and emotional intelligence have a significant impact on business performance.
\end{abstract}

Keywords: Islamic leadership; emotional intelligence; Islamic social entrepreneurship; MSE business performance

\section{Introduction}

Micro and Small Enterprises (MSEs) have always faced obstacles, such as recruitment, regulation, location, market, operational and technical, and finance (Pissarides, 1999). However, the challenger one country and another country had a unique characteristic. The low level of resources control by MSEs is an important dimension and processing time so that the level of wasted material is high. It caused of MSEs to operate in a narrow market, while customer satisfaction must be maintained. The research of Okręglicka et al. (2015) concluded that the role of MSEs is essential. Still, most of them do not recognize or apply complex management systems/approaches, or they are not aware of the challenges that arise from complex phenomena.

Meanwhile, the results of research by Musa \& Chinniah (2016) confirm that MSEs have an essential role in the nation's growth and face obstacles such as high raw material costs and initial investment, and burden of human resource skills, which are disturbing. Likewise, the Indonesian Government currently strengthens the MSE existence so that it has recorded an increasing contribution to GDP from $57.84 \%$ to 60.34\% (Depkop, 2018; BPS, 2019). MSEs are recognized as having extraordinary potential in sustainable development; therefore, it is necessary to increase their adaptability to a dynamic environment, which will impact the growth of SMEs. The lack of MSEs' ability to manage resources effectively and efficiently is a significant problem in developing MSEs (Sakur, 2011). The research of Meutia et al. (2018) shows that innovations carried out by SME managers will improve the performance of SMEs.

The factors that determine the success of MSEs in each country may not be the same because they relate to the number of workers, asset value, production capacity, essential characteristics of inputs, level of technology used, capital, management characteristics, and also economic development (Eniola \& Entebang, 2015). The performance measurement of MSEs is also different; some are determined based on the inherent characteristics and company strategy and the external environment (macroeconomy). Therefore, integrating the three determinants of SME performance into company characteristics, company strategy, and macroeconomic conditions will complete this research. Company characteristics and

1E-mail: asfiah@umm.ac.id 
strategies are internal factors, while macroeconomic conditions are external factors, often omitted in the company's growth analysis (Ipinnaiye et al., 2017). Based on a literature review and several research results, it can be described the factors that affect the performance of SMEs: the characteristics of SMEs, the characteristics of managers, and the way of doing business as internal factors that affect performance (Kemayel, 2015).

Islam teaches that good leadership adheres to the Qur'an and Hadith. In measuring Islamic leadership according to Wijayanti et al. (2012), as the leadership of the Prophet: 1) Asy-Shidq, namely truth, and sincerity in acting, speaking and struggling in carrying out their duties; 2) Al-Amanah or belief, which makes him take good care of what is given to him, both from God and from the people he leads, to create a sense of security for all parties; 3) Al-Fathanah, namely intelligence that gives birth to the ability to face and overcome problems that arise at once; 4) At-Tabligh, namely honest and responsible delivery, or it can also be called "openness." As an Islamic-based leadership model, the values espoused will inspire employees to act by the provisions of the Qur'an and Sunnah, which will provide the best benefit for their business. The results of research by Audretsch et al. (2013) argue that religion affects entrepreneurship in social entrepreneurship. Based on institutional theory, regulations regarding individuals of different religions, normative and cognitive dimensions differ significantly between religions, which raises an institutional profile that is conducive to or not conducive to entrepreneurship. Some religions have created institutions that facilitate and encourage entrepreneurship, such as the 'Aisyiyah organization, while others have created institutions that hurt entrepreneurial choices.

According to Goleman et al. (2002), one of the critical abilities in individuals and groups is Emotional Intelligence. Emotional intelligence accounts for $80 \%$ of the determinants of a person's success, while the other $20 \%$ is determined by Intelligence Quotient (IQ), as well as Waterhouse (2006). Emotional intelligence and job performance are defined as the extent to which an individual helps the organization achieve its various goals, according to Côté \& Miners (2006); and Borman \& Motowidlo (2009). The ability of entrepreneurs to be successful depends on their resilience and ability to innovate. The role of emotional intelligence in activating entrepreneurial innovation has not been widely explored in entrepreneurship research, which is divided into three areas of intelligence, namely abstract intelligence (the ability to understand and manipulate verbal and mathematical symbols), concrete intelligence (the ability to understand and use objects) and social intelligence (the ability to relate to others), by Ngah \& Salleh, (2015).

A study concludes that transformational leadership has a positive meaning about company performance in the sectors recommended to be institutionalized and ensure a sustainable competitive advantage in a fiercely competitive environment (Y1ld1z et al., 2014). The results of Husti \& Mahyarni's research (2019) found that Islamic leadership did not affect the performance of SMEs. Mushofa et al. (2014) show that leadership affects business performance by applying Islamic values, but the study describes the relationship between leaders and subordinates in an organization. A study also found that emotional intelligence in a group was not related to group performance (Prati et al., 2002). Meanwhile, this study was conducted on MSE groups whose cohesiveness is not in a shared vision and even competes with each other.

In this study, researchers consider it necessary to reveal MSEs in the creation of new social values based on Islamic values, such as Sakai et al. (2018), as research findings, that currently the spirit and interest of Muslims to build entrepreneurial participation by applying business ethics by Islamic values is relatively low (Ratten et al., 2017). This research is also motivated by the role of 'Aisyiyah as a socio-religious organization as an agent of change, which can improve people's welfare. The research results by Mulyaningsih \& Ramadani (2016) conclude that many research results in the realm of Islamic social entrepreneurship research are not based on a religious point of view due to the absence of spiritual relations. On the other hand, faith-based organizations also practice philanthropy and social entrepreneurship, such as Aisyiyah. Concerning these social values, the form of social entrepreneurship (Sociopreneurship) as the basis for MSEs is social-based entrepreneurship that is utilized for the benefit of the community, not only for personal gain; social entrepreneurship can be done individually or collectively by organization (Tan et al., 2005).

Social entrepreneurship is one of the alternative solutions in developing business innovation. In its implementation, the role of government and private institutions is needed that have the desire to overcome social problems which are at the same time related to the business world. With a high level of concern for the community's social conditions, efforts continue to be made to reach all levels of society through this social mission activity. The government plays a role in the work program of overcoming social problems; this is a vital asset for the government as an innovation driver to reform the existing social system. 


\section{Literature Review}

\section{Islamic social entrepreneurship}

Entrepreneurship has many definitions that are agreed upon. Still, at the same time not agreed upon, the argument is built like a business entity in general which requires good entrepreneurial conditions (Elizabeth, 2007) and becomes a discourse. However, from various addresses, there is a consensus on the notion of entrepreneurship, namely "understanding the existence of opportunities," is an attribute of entrepreneurship, such as goal-oriented behavior shown in the expression, namely creation of value. Meanwhile, Ghoul (2015) and Ramadani \& Ratten (2015) promote that entrepreneurship is part of Islamic culture. Therefore Islam invites all Muslims to become entrepreneurs.

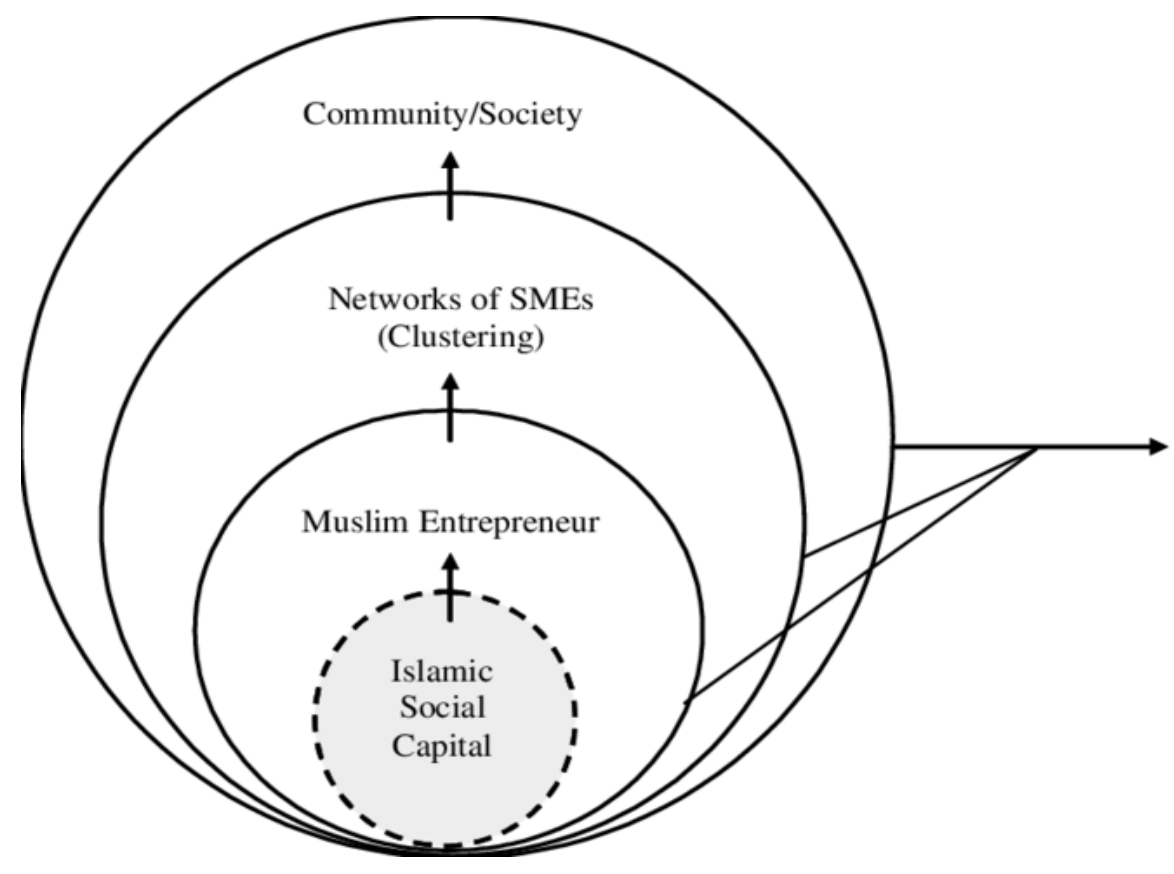

Islamic Social Entrepreneurship (al-Maidah: 2)

Figure 1. Islamic Social Entrepreneurship for SMEs Empowerment

The concept of social entrepreneurship as a business activity requires integrating various priority factors to meet needs. Once the resources are acquired, distributed, and managed to satisfy consumers, as a success factor related to the needs of society effectively. Its implementation requires a leader who has the initiative and is recognized, who instills a vision to be "sold" to others so that he gets support from others. The idea is usually wholly new and innovative, like the idea of a founder. Companies certainly need to realize something based on values that will later become evidence of the success of their business. A founder who is a natural entrepreneur will be committed to a successful business. Social entrepreneurship means "the creation of social value generated through collaboration with people and organizations from civil society engaged in social innovation which usually implies economic activity." This definition is based on four criteria: social values, civil society, innovation, and economic activity. Thoughts and developments on the meaning of entrepreneurship and entrepreneurship have been widely supported by sociological and political theories related to entrepreneurial behavior as the development of the concept of entrepreneurship and entrepreneurship. Entrepreneurship theory is conceptualized from various critical views of applying trait theory to "entrepreneurial personality" and the lack of research findings on entrepreneurial traits (Chell, 2008).

Social entrepreneurship requires some combination of visionary ideas, people with leadership skills, and a commitment to make things happen. And at the same time, people who are committed to helping others. Micro, Small, and Medium Enterprises (MSMEs) have been considered major players in domestic economic activities (Abdullah \& Hoetoro, 2011). Social entrepreneurship is in line with Islamic ideals, and in line with Islamic values that regulate muammalah (relationships) between humans and their environment to meet needs. According to the scholars, these needs can be categorized into 1) darruriyyat needs (basic needs), which consist of the needs: ad-dien, an-nafs, al-aql, an-nasl, and al-maal; while the second category is the needs of hajjiyyat; and 3) the need for tahsiniyyah as stated by Sidik (Ratten et al., 2017), which has 
also been supported by the research results of Zain et al., (2013). Fulfillment of darruriyyat needs is the most critical need, taking into account the benefit. Therefore this darruriyyat need must be maintained. In other words, this need must be met first before fulfilling the following need, namely the need for hajjiyyat and the need for tahsiniyyah. The need for hajiyat is a need that can prevent humans from living difficulties, and the need for tahsiniyat is a need that supports increasing the dignity of one's life in society and before Allah SWT, within the limits of fairness and decency.

Therefore, A. Wahab Khalaf explained that if the ranking of these needs has been fulfilled perfectly, the human benefit has been realized, which is the goal of sharia law. The presence of successful Muslim entrepreneurs has the role of being a role model in the economic success of Muslims. The activities carried out by this group are economic activities based on Islamic law and are far from elements that violate religious rules. The involvement of this group in the economic field will serve as an example for the community and other entrepreneurs to run a business based on Islamic law, as Fig.1.

\section{Islamic Leadership}

People live in groups in a unified social system, both in profit and non-profit organizations, and Wirawan describes the anatomy of the social system as follows Wirawan (2014) as seen in Fig. 2. Islam teaches that good leadership is leadership that always adheres to the Qur'an and Hadith. Indicators to measure Islamic leadership, according to Wijayanti et al. (2012), namely: 1) Ash-Shidq, namely truth, and sincerity in acting, speaking, and fighting in carrying out their duties; 2) Al-Amanah or Amanah, which makes him take the best care of what has been handed over to him either from God or from the people he leads, to create a sense of security for all parties; 3) Al-Fathanah, namely intelligence that gives birth to the ability to face and overcome problems that arise even at once; 4) At-Tabligh, namely honest and responsible delivery, or can be termed "openness."

Social capital has a direct positive impact on company performance. Researchers have also identified innovation as a critical determinant of organizational success and for gaining competitive advantage. Developing social network relationships can be caused by social capital, can help create new knowledge from the relationship, lead to the exchange of skills among employees, build the necessary trust to develop these skills, motivation to develop understanding, recognize the value of new knowledge, and information and also put it into practice (Agyapong et al., 2017).

H1: Islamic leadership influences the Islamic social entrepreneurship

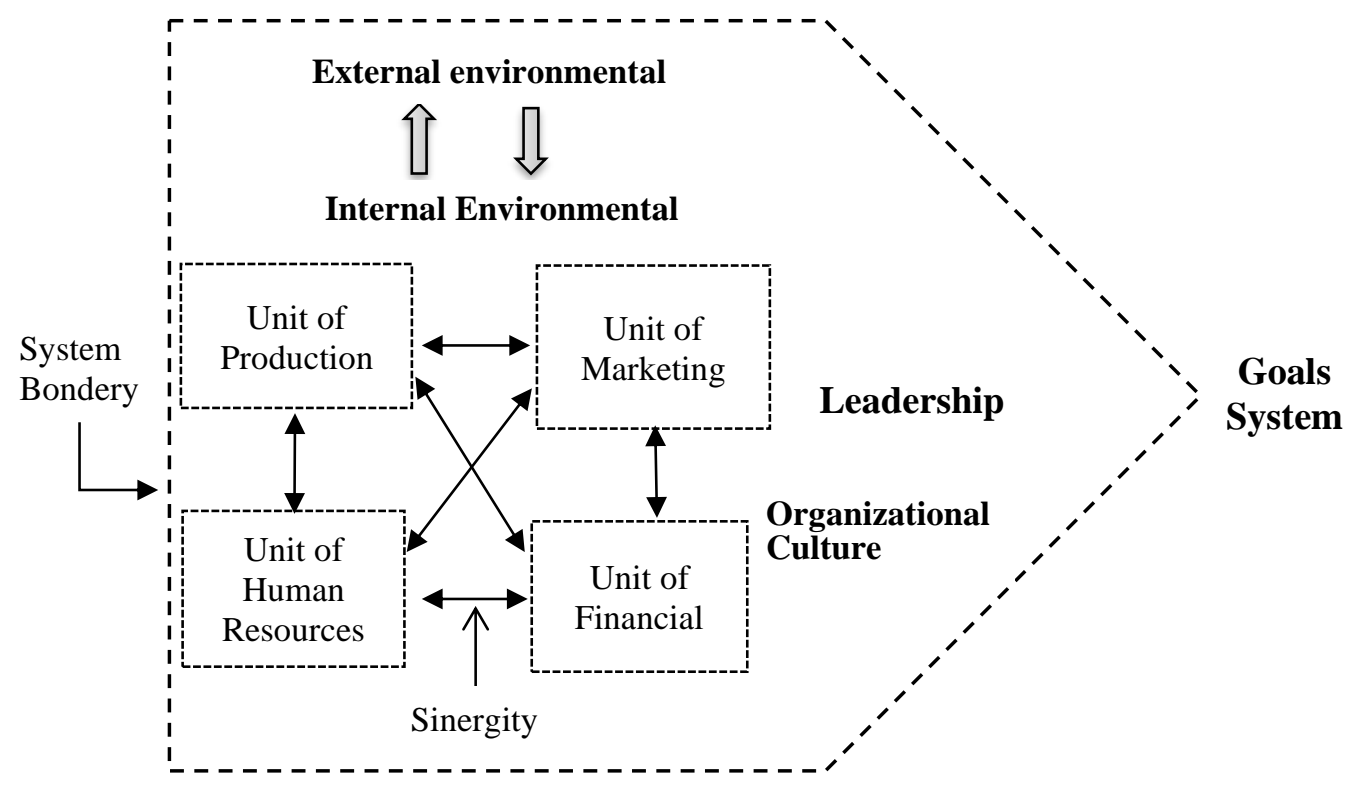

Figure 2. Anatomy of social business system

\section{Emotional Intelligence}

Emotional intelligence is the ability to feel and understand more effectively the power of emotional sensitivity, which includes the ability to motivate oneself or others, self-control, being able to understand 
other people's feelings effectively, and being able to manage emotions that can be used to guide the mind to make the best decisions. Goleman states that good emotional intelligence can be identified through five essential components (Robbins \& Judge, 2013). The components are: 1) Self-awareness (self-knowledge), which can recognize emotions and the causes of the triggers of these emotions. 2) Self-regulation (selfcontrol), namely someone who has good self-knowledge, can be more controlled in making actions to be more careful. 3) Self-motivation, i.e., when something goes not according to plan, someone who has high emotional intelligence will not ask, "What's wrong with me or us?". Instead, he asks, "What can we do so that we can fix this problem?". 4) Empathy, namely the ability to recognize the feelings of others and feel what others feel if they are themselves in that position. 5) Effective Relationship, namely with the four abilities, a person can communicate with others effectively. The ability to solve problems together is emphasized rather than on unimportant confrontations that could otherwise be avoided. People who have high emotional intelligence have constructive goals in mind.

Someone who does not have high emotional intelligence can be characterized by the following: have heightened emotions, act quickly on their feelings, and are not sensitive to the feelings of others. People who do not have high emotional intelligence usually tend to hurt and be hostile to others. In small businesses, people need to manage their impulses, communicate with others effectively, manage change well, solve problems, and build good relationships intense situations. They also need empathy and remain optimistic even in the face of adversity. This study shows Emotional Intelligence improves performance (Sabatier, 2013).

The result of research by Ngah \& Salleh (2015), also highlighted the importance of emotional intelligence in driving innovation among entrepreneurs. Other findings also explain that emotional intelligence inspires and motivates employees to be innovative and creative in their organizations. In addition, this study also suggests that emotional intelligence should be explored in another more adequate perspective.

\section{H2: Emotional Intelligence influences Islamic social entrepreneurship}

\section{Micro and Small Firm}

Small and medium enterprises (SMEs) have the most dynamic potential in a developing economy. MSEs are most likely to shift to areas of comparative advantage and high added value, despite facing economic, institutional, and legal barriers, in the form of limited access to working capital and long-term credit, laws, and regulations, inadequate infrastructure, high transaction costs, and little managerial and technical expertise (Pissarides, 1999).

Company performance is a measure used to measure the company's success in achieving the goals that have been set, where this performance can be measured through 3 things, namely efficiency, coordination, and trade (market position and sales). But according to Munizu (2010) mentions the factors that affect the performance of MSMEs are aspects of human resources, financial aspects, technical aspects of production and operations, market and marketing aspects, aspects of government policies, social, cultural, and economic factors, as well as aspects of the role of related institutions. The business performance of the MSEs can be detailed as follows: 1) sales growth rate/sales turnover; 2) capital/financial growth rate; 3) labor growth rate, and 4) market growth rate, and 5) the rate of profit (profit growth).

The description of successful MSEs can be explained as follows. First, micro Enterprises, seen from: a) types of goods/commodities are not permanently fixed; may change at any time; b) the place of business is not always permanent; can change places at any time; c) have not carried out even a simple financial administration; d) do not separate family finances from business finances; e) Human resources (entrepreneurs) do not yet have an excellent entrepreneurial spirit; f) The average level of education is relatively meager; g) Generally have not accessed banking, but some have access to non-bank financial institutions, do not have a business license or other legal requirements including Taxpayer Identification Number. Example: trading businesses such as street vendors and traders in the market.

Second, Small Businesses, seen from: a) types of goods/commodities being cultivated are generally not easy to change; b) the location/place of business is generally settled and not moving; c) In general, they have carried out financial administration although it is still simple, d) company finances have begun to be separated from family finances; e) have made a business balance; f) already have a business license and other legal requirements including Taxpayer Identification Number; g) human resources (entrepreneurs) have experience in entrepreneurship, and h) Some have access to banks for capital purposes, and i) Most of them have not been able to make sound business management such as business planning. Example: Traders in wholesale markets (agents) and other traders and collectors. 
MSEs can be classified into four groups: 1) lvelihood Activities, are SMEs used as job opportunities to earn a living, which is more commonly known as the informal sector. Examples are street vendors; 2) Micro Enterprise, is an SME that has the nature of craftsmen but does not yet have the heart of entrepreneurship; 3) Small Dynamic Enterprise, is an SME that already has an entrepreneurial spirit and can accept sub-contract and export work; and 4) Fast Moving Enterprise, which is an SME that already has an entrepreneurial spirit and will transform into a Big Business. One of Indonesia's legal products that become a reference and development for SMEs is Law no. 20 of 2008 concerning Micro, Small, and Medium Enterprises (UU No. 20, 2008).

This study will use financial and non-financial measures to measure the performance of SMEs; such as sales growth, profit growth, employee growth, turnover, market share growth, customer satisfaction, and retention as shown by Dess et al. (1997), and strengthen research results by Zaato et al., (2020). Although the study results of Husti \& Mahyarni (2019) show that Islamic Leadership does not affect the performance of MSEs, the results of the survey of Mushofa et al. (2014) show that leadership by applying Islamic values affects performance. Meanwhile, the results of other studies concluded that the attributes of emotionality (capacity for relationship skills, empathy, emotional perception, and expression) and self-control ability to manage emotions, drive, and manage stress) play a role in improving performance (Webb, 2012).

\section{H1.a: Islamic social entrepreneurship moderated of influence Islamic Leadership to Business Performance \\ H2.a: Islamic social entrepreneurship moderated of influence Emotional Intelligence to Business Performance}

\section{Research Method}

The population is a subject with specific characteristics and can be used as a research sample (Umar, 2005). The population in this study were MSEs fostered by 'Aisyiyah, The Women's Mass Organizations. The population number will be selected to serve as a sample representative of the population (Sekaran, 2003). This research is a quantitative approach, with a population of MSEs coached by 'Aisyiyah, and respondents are determined, 150 people. This number counted from a total number of research indicators, based on non-random/non-probability sampling, using judgmental technique sampling, based on certain opinions or considerations, without considering the subject taken as a sample representing the population, sub-population or not (Ferdinand, 2006).

There are four variables and 30 indicators, and the result of the sample counted from $\mathrm{n}=30 \times 5$; the number of responden is determined 150 people of the member SMEs. It is cause there is no definite number of the existing population, as for the collection of the questionnaire using Google form. Data analysis to see the direct effect of Islamic leadership variables and emotional intelligence on MSEs business performance and the indirect influence with the mediation of Islamic social entrepreneurship variables used path analysis techniques with the Smart-PLS 3.0 software. The results of the analysis show that there are significant direct and indirect effects of these variables. The data was collected using a questionnaire that has been developed by the variable items observed in this study. Questionnaires distributed to respondents were sent to respondents using Google form as many as 150 people, and all forms were filled in and returned (Sugiyono, 2018).

The measurement scale used in this study is a Likert scale (Sekaran, 2003); it's used to describe how strongly the subject agrees or disagrees with the statement using a five-point scale. This study uses Islamic Leadership, Emotional Intelligence, Islamic social entrepreneurship as moderating, and Business Performance. Meanwhile, research data analysis using Smart-PLS, including path analysis, extends multiple linear regression analysis. Path analysis was used to test the effect of the moderating variables that became the model in this study (Ghozali \& Latan, 2015). In detail, these variables describe on operational variables in Table 1.

\section{Result and Discussion}

This study consists of independent variables: Islamic Leadership and Emotional Intelligence, Islamic social entrepreneurship as moderating, and Business Performance as a dependent. Using 150 respondents, it can be illustrated that based on gender, MSEs can be grouped as $64 \%$ women and $36 \%$ men. If viewed from the marital status, it can be categorized that $80 \%$ are married, and $20 \%$ are not / unmarried. In the classified education category, $50 \%$ have a high school education, $23 \% \mathrm{~S} 1$, and $27 \% \mathrm{~S} 2$. As for the types of business can be categorized, $51 \%$ in food and beverage businesses, $21 \%$ in service businesses, $21 \%$ in retail companies, $4 \%$ in health drinks, and $3 \%$ in home industry skills (crafts). Based on outer model of all items, there are valid and significant, as Table 3. The results of data analysis can be explained the 
influence of Islamic leadership variables, emotional intelligence, directly or indirectly on business performance, which is formed using the type of reflexive indicator, and moderated by Islamic social entrepreneurship variables shown in the following Figure 3.

Table 1. Operational Variables

\begin{tabular}{|c|c|c|}
\hline Variables & Definition & Indicators \\
\hline $\begin{array}{l}\text { Islamic } \\
\text { Leadership }\end{array}$ & $\begin{array}{l}\text { Islam teaches that good leadership is leadership that } \\
\text { always adheres to the Al-Qur'an and Hadith, as the } \\
\text { role model of The Prophet: Shidq, Amanah or belief, } \\
\text { Fathanah, and Tabligh; modified from any sources } \\
\text { (Wijayanti et al., 2012) (Wirawan, 2014) and hadith. }\end{array}$ & $\begin{array}{ll}\text { 1. } & \text { Integrity } \\
\text { 2. } & \text { Truth \& sincerity in attitude } \\
\text { 3. } & \text { Take good care } \\
\text { 4. } & \text { Create a sense of security for all } \\
\text { 5. Intelligence and overcome } \\
\text { problems } \\
\text { 6. Honest and responsible } \\
\text { 7. } \\
\end{array}$ \\
\hline $\begin{array}{l}\text { Emotional } \\
\text { Intelligence }\end{array}$ & $\begin{array}{l}\text { The ability to feel and understand more effectively } \\
\text { the power of emotional sensitivity which includes the } \\
\text { ability to motivate oneself or others, self-control, } \\
\text { being able to understand other people's feelings } \\
\text { effectively, and being able to manage emotions that } \\
\text { can be used to guide the mind to make the best } \\
\text { decisions; modified from (Goleman et al., 2002; and } \\
\text { Robbins \& Judge, 2013) }\end{array}$ & 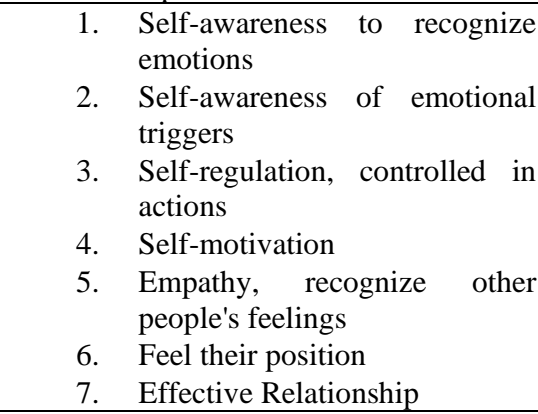 \\
\hline $\begin{array}{l}\text { Islamic social } \\
\text { entrepreneurs } \\
\text { hip }\end{array}$ & $\begin{array}{l}\text { Social entrepreneurship is in line with Islamic ideals } \\
\text { and line with Islamic values (Ratten et al., 2017, and } \\
\text { Zain et al., 2013); by emphasizing social } \\
\text { interdependence, to develop towards society } \\
\text { prosperous, united and peaceful, by promoting a } \\
\text { balance between community and business } \\
\text { development; (Abdullah \& Hoetoro, 2011) and Al- } \\
\text { Qur'an (Al Maidah: 2) }\end{array}$ & $\begin{array}{ll}\text { 1. } & \text { Improving to community } \\
\text { 2. } & \text { Equare } \\
\text { 3. } & \text { Responsibility to social issues } \\
\text { 4. } & \text { Initiative \& innovative } \\
\text { 5. } & \text { Support to community } \\
\text { 6. } & \text { Sincerely } \\
\text { 7. } & \text { Being friendly } \\
\text { 8. } & \text { Shared } \\
\text { 9. } & \text { Business is not prohibited } \\
\end{array}$ \\
\hline $\begin{array}{l}\text { Business } \\
\text { Performance }\end{array}$ & $\begin{array}{l}\text { Factors that affect the performance of MSEs are } \\
\text { human resources, financial aspects, technical aspects } \\
\text { of production and operations, market and marketing } \\
\text { aspects, government policy aspects, social, cultural, } \\
\text { and economic aspects, and so aspects of the role to } \\
\text { relate institutions; modified from Munizu (2010). }\end{array}$ & $\begin{array}{ll}\text { 1. } & \text { Human resource quality } \\
\text { 2. } & \text { Funding access } \\
\text { 3. } & \text { Quality product } \\
\text { 4. } & \text { New market niches } \\
\text { 5. } & \text { Networking } \\
\text { 6. } & \text { Profit growth } \\
\text { 7. } & \text { Strategies } \\
\end{array}$ \\
\hline
\end{tabular}

\section{Direct effect}

The Direct effect shows the immediate impact of exogenous variables in endogenous variables without involving the mediating variable. The estimation results of the inner model for the direct effect of IL on ISE show the path coefficient value of 0.279 with a p-value of 0.000 which is smaller than alpha 0.05 $(\alpha=5 \%)$, which shows that the direct effect of IL on ISE is significant. The result is positive, which means that the better IL, the ISE will also increase. And vice versa, the less good IL is, the ISE will also decrease.

The estimation results of the inner model for the direct effect of EI on ISE show the path coefficient value of 0.226 with a p-value of 0.001 , which is smaller than alpha $0.05(\alpha=5 \%)$, which shows that the direct effect of EI on ISE is significant. The result is positive, which means that the better EI, the ISE will also increase. And vice versa, the less good EI is, the ISE will also decrease.

The estimation result of the inner model for the direct effect of ISE on BP shows the path coefficient value of 0.373 with a p-value of 0.000 which is smaller than alpha $0.05(\alpha=5 \%)$, which indicates that the direct effect of ISE on BP is significant. The result is positive, which means that the better ISE, the $\mathrm{BP}$ will also increase. On the other hand, the less good ISE is, the BP will also decrease.

The path coefficient value for the indirect effect between IL through ISE on BP is 0.104 with a pvalue of 0.007 , which is smaller than 0.05 , so it can be concluded that the indirect effect between IL through 
ISE on BP is significant. This means, the better IL, it will affect the increase in ISE, so that an increase in ISE will affect the rise in BP.

The value of the path coefficient for the indirect effect between EI through ISE on BP is 0.084, which indicates that the p-value is 0.012 , which is smaller than 0.05 , so it can be concluded that the indirect effect between EI through ISE on BP is significant. The better EI, the increase in ISE will be so that an increase in ISE will affect the rise in BP.

Table 2. The output of measurement variables

\begin{tabular}{|c|c|c|c|c|}
\hline \multicolumn{2}{|c|}{ Indicators of Islamic Leadership (IL) } & T Statistics & P Values & Significancy \\
\hline 1. Integ & Integrity & 22.830 & 0.000 & significance \\
\hline 2. Truth & Truth \& sincerity in attitude & 16.499 & 0.000 & significance \\
\hline 3. Take & Take good care & 14.615 & 0.000 & significance \\
\hline 4. Creat & Create a sense of security for all & 30.142 & 0.000 & significance \\
\hline 5. Intell & Intelligence and overcome problems & 16.046 & 0.000 & significance \\
\hline 6. Hone & Honest and responsible & 28.943 & 0.000 & significance \\
\hline 7. Open & Openness & 19.559 & 0.000 & significance \\
\hline \multicolumn{5}{|c|}{ Indicators of Emotional Intelligence (EI) } \\
\hline 8. Self-c & Self-awareness to recognize emotions & 12.757 & 0.000 & significance \\
\hline 9. Self-a & Self-awareness of emotional triggers & 15.616 & 0.000 & significance \\
\hline & Self-regulation, controlled in actions & 12.591 & 0.000 & significance \\
\hline 11. Self- $n$ & Self-motivation & 15.605 & 0.000 & significance \\
\hline 12. Empa & Empathy, recognize other people's feelings & 13.955 & 0.000 & significance \\
\hline 13. Feel $\mathrm{t}$ & Feel their position & 11.357 & 0.000 & significance \\
\hline 14. Effect & Effective Relationship & 16.309 & 0.000 & significance \\
\hline \multicolumn{5}{|c|}{ Indicators of Islamic social entrepreneurship (ISE) } \\
\hline 15. Impro & Improving to community welfare & 21.886 & 0.000 & significance \\
\hline 16. Equal & Equality & 33.603 & 0.000 & significance \\
\hline 17. Respc & Responsibility to social issues & 22.088 & 0.000 & significance \\
\hline & Initiative \& innovative & 25.140 & 0.000 & significance \\
\hline 19. Supp & Support to community & 36.156 & 0.000 & significance \\
\hline 20. Since & Sincerely & 24.221 & 0.000 & significance \\
\hline 21. Being & Being friendly & 18.955 & 0.000 & significance \\
\hline 22. Share & Shared & 14.216 & 0.000 & significance \\
\hline 23. Busin & Business is not prohibited & 23.410 & 0.000 & significance \\
\hline Indicators of $\mathrm{Bl}$ & iness Performance (BP) & & & \\
\hline 24. Huma & resource quality & 51.466 & 0.000 & significance \\
\hline 25. Fundi & g access & 91.653 & 0.000 & significance \\
\hline 26. Quali & product & 59.130 & 0.000 & significance \\
\hline 27. New & arket niches & 35.231 & 0.000 & significance \\
\hline 28. Netw & king & 28.016 & 0.000 & significance \\
\hline 29. Profit & rowth & 20.022 & 0.000 & significance \\
\hline 30. Strate & & 25.496 & 0.000 & significance \\
\hline & Table 3. Direct al & Indirect Effec & & \\
\hline Hypothesis & Path Coefficient & t-statistics & P Values & Significancy \\
\hline $\mathrm{H} 1$ & ISE -> BP & 5.260 & 0.000 & Significance \\
\hline $\mathrm{H} 2$ & IL $\quad>$ ISE & 4.267 & 0.000 & Significance \\
\hline $\mathrm{H} 3$ & EI $\rightarrow$ ISE & 3.349 & 0.001 & Significance \\
\hline H1a & $\begin{array}{l}\text { IL }->\text { ISE }-> \\
\text { BP }\end{array}$ & 2.687 & 0.007 & significance \\
\hline $\mathrm{H} 2 \mathrm{a}$ & $\begin{array}{l}\text { EI }->\text { ISE -> } \\
\text { BP }\end{array}$ & 2.518 & 0.012 & significance \\
\hline
\end{tabular}

Aspects of Islamic leadership (IL), which include integrity, truth, and sincerity in acting, being careful, creating a sense of security for all, being intelligent and able to solve problems, being honest and responsible, and having openness, have been carried out by the business owners of MSEs. This condition supports the results of research from Wijayanti et al. (2012), that Islamic leadership can accept suggestions, opinions, and criticism from subordinates, the ability to work together in achieving goals, the ability to identify personal goals with organizational goals, dependence on formal power, the ability to participate in group activities, and responsibility for the work that is owned. And these conditions will have an impact on highly the business performance achievement. 
Leadership in Islam has a vital role that encourages and supports life by guiding in all aspects of life. In the concept of Islam, the leader must set an example by the example of the Prophet, as the results of research conducted by Abdallah et al. (2019). He also explained that leaders in Islam follow the principles: 1) servant leadership, 2) transformational leadership, 3) ethical leadership, and 4) situational leadership. With these principles, a leader will be a determinant of business success by maintaining the social framework of entrepreneurship.

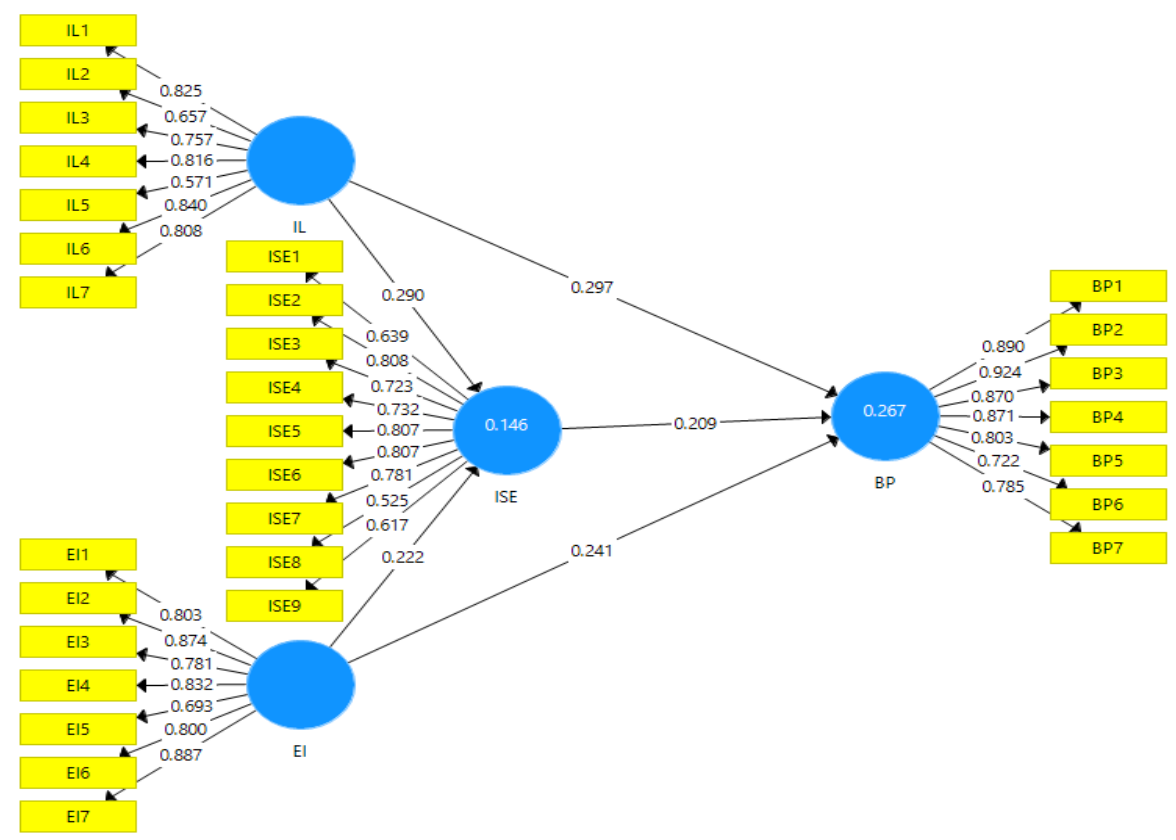

Figure 3. Structural Equation of Path Diagram

While emotional intelligence (EI), which includes self-awareness in recognizing emotions, selfawareness of emotional triggers, self-regulation, control in acting, self-motivation, empathy, acknowledging other people's feelings, being able to feel their position, and effective relationships, has also been shown to have an impact significant impact on business performance, and this is in line with Goleman et al., (2002) statement. Islamic social entrepreneurship (ISE) also has a role in moderating the influence of emotional intelligence on business performance in this study. These results show the results are in line with the results study of Abdullah \& Hoetoro (2011), which expresses a new thought, which initiates Islam to examine the role and obstacles to the development of MSEs with Islamic-based social entrepreneurship. Furthermore, this study found that Islamic business requires Islamic social capital, which MSEs need in carrying out Islamic social entrepreneurship. The application of Islamic social entrepreneurship will produce great work and value for the community. So that a business is not just looking for profitability for shareholders, with professional, accountable, and efficient business behavior.

Islamic social entrepreneurship (ISE) is also has a significant direct effect on the business performance of MSEs. Meanwhile, it is slightly different from the results of the Delphi study, which provides an overview of the items recommended for the dimensions of social entrepreneurship chosen by Kraus et al. (2017), which consist of social innovation, social risk-taking, and being socially proactive. Research with social entrepreneurship is mainly carried out in the Western world based on Christian values. It is different from current research, which conducts studies based on Islamic values. The term Islamic social entrepreneurship (ISE) is still relatively new in theory and research. Entrepreneurship in the Islamic perspective is very concerned with the principles of thought, which are affirmed in two ways, as Mulyaningsih \& Ramadani (2016) stated. First, Islam encourages the development of entrepreneurship and entrepreneurship as an integral part of its religion. Second, in the perspective of ownership of resources and property, Muslims are caliphs and agents of Allah's trust responsible for generating prosperity and consider that doing business is part of worship or good deeds. Third, in the perspective of business success, the most important thing is the benefit of the people (cooperation for existence) and living ethically by the philosophy of faith in Allah SWT.

Furthermore, the study results that describe emotional intelligence (EI) have a significant effect on the business performance of MSEs. These results are in line with the research results from Pratama \& 
Suhaeni (2018), which shows that there is a strong and significant positive relationship between emotional intelligence and performance. According to Waris (2015), about achieving high performance, it is necessary to use several approaches, one of which is the psychological approach of the employees themselves, namely how a person maintains his emotions. Psychological techniques to performance include personality and emotional intelligence approaches. Goleman et al. (2002) revealed that self-awareness would affect performance because it determines the goals someone achieves. This also shows a positive and significant influence between emotional intelligence and MSE performance on the study Yuningsih et al., (2018), using multiple linear regression models.

This research implies that social entrepreneurship based on Islamic values has become a culture. Even Islam teaches the door of sustenance, which is mostly from entrepreneurship, supported by the research results of Ghoul (2015). The verse of the Qur'an Surah Al Maidah (2) also confirms: And help you in (doing) goodness and righteousness, and do not help in sin and enmity. Attention to the concept of Islamic social entrepreneurship is essential to develop a further entrepreneurial activity that describes a social nature, which does not seek only profit but the common good or benefit. The current study of the concept of Islamic social entrepreneurship is to see its effect on improving business performance in MSEs, with the support of Islamic leadership and emotional intelligence, as well as data analysis which results show that these variables have a significant effect. The study of Islamic social entrepreneurship needs to be developed and promoted to solve social and economic problems simultaneously by linking it with various other variables.

\section{Conclusions, suggestions and limitations}

The results of this study indicate that Islamic social entrepreneurship has a central role in improving the business performance of MSEs. The part of Islamic social entrepreneurship in this study can moderate Islamic leadership and emotional intelligence in improving the business performance of MSEs. In this case, Islamic social entrepreneurship directly or indirectly affects MSE's business performance. Based on the results of this study, the business performances need to be managed better by strengthening the implementation of Islamic social entrepreneurship; this is because the MSEs group coaching by 'Aisyiyah is a group formed from socio-religious activities. The results of this study can be used as a reference for the development of the 'Aisyiyah economic program in fostering and developing MSEs so that there are to ensure the sustainability of the MSEs. In addition, this research can also be developed with various other supporting variables and a broader area, considering that this research is limited to the East Java Region.

\section{References}

Abdallah, A., Çitaku, F., Waldrop, M., Zillioux, D., Preteni Çitaku, L., \& Hayat Khan, Y. (2019). A Review of Islamic Perspectives on Leadership. IJSRM-International Journal of Scientific Research and Management, 7(11), 574-578. https://doi.org/10.18535/ijsrm/v7i11.sh02

Abdullah, M. A., \& Hoetoro, A. (2011). Social Entrepreneurship as an Instrument to Empowering Small and Medium Enterprises: An Islamic Perspective. Int. J. Manag. Bus. Res, 1(1), 35-46.

Agyapong, F. O., Agyapong, A., \& Poku, K. (2017). Nexus between social capital and performance of micro and small firms in an emerging economy: The mediating role of innovation. Cogent Business and Management, 4(1), 1-20. https://doi.org/10.1080/23311975.2017.1309784

Audretsch, D. B., Bönte, W., \& Tamvada, J. P. (2013). Religion, social Class, and Entrepreneurial Choice. Journal of Business Venturing, 28(6), 774-789. https://doi.org/10.1016/j.jbusvent.2013.06.002

Borman, W. C., \& Motowidlo, S. J. (2009). Task Performance and Contextual Performance: The Meaning for Personnel Selection Research. Journal of Computer and Systems Sciences International, 43(1), $136-144$.

BPS. (2019). Potensi Peningkatan Kinerja Usaha Mikro Kecil.

Chell, E. (2008). Who is an entrepreneur? In The Entrepreneurial Personality. https://doi.org/10.4324/9780203938638.ch1

Côté, S., \& Miners, C. T. H. (2006). Emotional Intelligence, Cognitive Intelligence, and Job Performance. JSTOR, 51(1), 1-28. http://www.jstor.org/stable/20109857

Depkop. (2018). Perkembangan Data Usaha Mikro, Kecil, Menengah Dan Usaha Besar. In www.depkop.go.id (Vol. 2000, Issue 1).

Dess, G. G., Lumpkin, G. T., \& Covin, J. G. (1997). Entrepreneurial Strategy Making and Firm Performance: Tests of Contingency and Configurational Models. Strategic Management Journal, 18(9), 677-695. https://doi.org/10.1002/(sici)1097-0266(199710)18:9<677::aid-smj905>3.3.co;2-h 
Elizabeth, C. (2007). Social Enterprise and Entrepreneurship: Towards A Convergent Theory of The Entrepreneurial Process. International Small Business Journal, 25(1), 5-26. https://doi.org/10.1177/0266242607071779

Eniola, A. A., \& Entebang, H. (2015). SME Firm Performance-Financial Innovation and Challenges. Procedia - Social and Behavioral Sciences, 195, 334-342. https://doi.org/10.1016/j.sbspro.2015.06.361

Ferdinand, A. (2006). Structural Equation Modelling dalam Penelitian Manajemen (Edisi Empa). Program Magister Manajemen Universitas Diponegoro.

Ghoul, W. A. (2015). Entrepreneurship within the framework of Shari'ah. International Journal of Business and Globalisation, 15(3), 262-271. https://doi.org/10.1504/ijbg.2015.071904

Ghozali, I., \& Latan, H. (2015). Partial Least Squares Konsep, Teknik Dan Aplikasi Menggunakan Program Smartpls 3.0 Untuk Penelitian Empiris (Edisi 2). Universitas Diponegoro.

Goleman, D., Hartel, C., Boyatzis, R., \& Mckee, A. (2002). The Emotionally Intelligent Workplace: How to Select For, Measure, and Improve Emotional Intelligence In Individuals, Groups, And Organizations. Administration In Social Work.

Husti, I., \& Mahyarni, M. (2019). Islamic Leadership, Innovation, Competitive Advantages, and Performance of SMEs in Indonesia. East Asia Springer, 36(4), 369-383. https://doi.org/10.1007/s12140-019-09325-7

Ipinnaiye, O., Dineen, D., \& Lenihan, H. (2017). Drivers of SME performance: a holistic and multivariate approach. Small Business Economics, 48(4), 883-911. https://doi.org/10.1007/s11187-016-9819-5

Kemayel, L. (2015). Success Factors of Lebanese SMEs: An Empirical Study. Procedia - Social and Behavioral Sciences, 195, 1123-1128. https://doi.org/10.1016/j.sbspro.2015.06.158

Kraus, S., Niemand, T., Halberstadt, J., Shaw, E., \& Syrjä, P. (2017). Social Entrepreneurship Orientation: Development of A Measurement Scale. International Journal of Entrepreneurial Behaviour and Research, 23(6), 977-997. https://doi.org/10.1108/IJEBR-07-2016-0206

Meutia, M., Ismail, T., \& Ummi, N. (2018). Leadership Issue and SME Performance During Crisis. International Journal of Civil Engineering and Technology, 9(4), 424-435. http://www.iaeme.com/ijciet/issues.asp?JType=IJCIET\&VType=9\&IType $=4$

Mulyaningsih, H. D., \& Ramadani, V. (2016). Social entrepreneurship in an Islamic context. In Entrepreneurship and Management in an Islamic Context. https://doi.org/10.1007/978-3-319-39679$8 \_10$

Munizu, M. (2010). Pengaruh Faktor-Faktor Eksternal dan Internal Terhadap Kinerja Usaha Mikro dan Kecil (UMK) di Sulawesi Selatan. Jurnal Manajemen Dan Kewirausahaan, 12(1), 33-41. https://doi.org/10.9744/jmk.12.1.pp.33-41

Musa, H., \& Chinniah, M. (2016). Malaysian SMEs Development: Future and Challenges on Going Green. Procedia - Social and Behavioral Sciences, 224(August 2015), 254-262. https://doi.org/10.1016/j.sbspro.2016.05.457

Mushofa, A., Mursinto, D., \& Anam, S. (2014). Influence Of The Islamic Leadership To Participation Of The Members, Business Performance And Prosperity Of The Members Of Syari'ah Financial Service Cooperative In East Kalimantan Province. European Journal of Business and Management, 6(38), 217-226.

Ngah, R., \& Salleh, Z. (2015). Emotional Intelligence and Entrepreneurs' innovativeness towards Entrepreneurial Success: A Preliminary Study. American Journal of Economics, 5(2), 285-290. https://doi.org/10.5923/c.economics.201501.37

Okręglicka, M., Gorzeń-Mitka, I., \& Ogrean, C. (2015). Management Challenges in the Context of a Complex View - SMEs Perspective. Procedia Economics and Finance, 34(15), 445-452. https://doi.org/10.1016/s2212-5671(15)01653-6

Pissarides, F. (1999). Is Lack of Funds The Main Obstacle to Growth? EBRD's Experience With SmallAnd Medium-Sized Businesses In Central And Eastern Europe. Journal of Business Venturing, 14(5), 519-539. https://doi.org/doi.org/10.1016/S0883-9026(98)00027-5

Pratama, A. Y., \& Suhaeni, T. (2018). Pengaruh Kecerdasan Emosional terhadap Kinerja Karyawan. Jurnal Riset Bisnis Dan Investasi, 3(2), 51. https://doi.org/10.35697/jrbi.v3i2.933

Prati, L. M., Douglas, C., Ferris, G. R., Ammeter, A. P., Buckley, M. R., \& Rapisarda, B. A. (2002). The Impact of Emotional Intelligence on Work Team Cohesiveness and Performance. The International Journal of Organizational Analysis, 10(4), 363-379. https://doi.org/10.1108/eb028958

Ramadani, V., \& Ratten, V. (2015). The context of Islamic entrepreneurship and business : Concept , principles and perspectives The context of Islamic entrepreneurship and business: concept , principles and perspectives Veland Ramadani * Léo-Paul Dana Vanessa Ratten Sadush Tahiri. 
International Journal of Business and Globalisation, 15(January), 244-261.

Ratten, V., Alamanda, D. T., Ramadani, V., Hashani, M., \& Anggadwita, G. (2017). Entrepreneurial intentions from an Islamic perspective: a study of Muslim entrepreneurs in Indonesia. International Journal of Entrepreneurship and Small Business, 165. https://doi.org/10.1504/ijesb.2017.10004845

Robbins, S. P., \& Judge, T. A. (2013). Organizational Behavior (S. Yagan (ed.); 15th ed.). Pearson Education, Inc., publishing as Prentice Hall.

Sabatier, M. (2013, August). How to use 'Emotional Intelligence' to improve performance and working culture. Business Matters UK's LEADING BUSINESS MAGAZINE. https://bmmagazine.co.uk/opinion/how-to-use-emotional-intelligence-to-improve-performance-andworking-culture/

Sakai, M., Puspitasari, D. C., Isbah, M. F., Ryandono, M. N. H., BS., H. C., \& LA., E. Z. (2018). Kontribusi Islam Indonesia terhadap Pembangunan Sosial Ekonomi. In D. C. Puspitasri (Ed.), Kewirausahaan Sosial - Tinjauan Konsep Dan Terapan Dalam Organisasi Sosial Islam (1st ed., pp. 13-26). Tiara Wacana. www.tiarawacana.co.id

Sakur. (2011). Kajian Faktor-Faktor yang Mendukung Pengembangan Usaha Mikro Kecil dan Menengah. Spirit Publik, 7(2), 85-109.

Sekaran, U. (2003). Research and Markets: Research Methods for Business - A Skill Building Approach. In John Wiley \& Sons. John Wiley and Sons. https://docs.google.com/viewer?a=v\&pid=sites\&srcid=ZGVmYXVsdGRvbWFpbnxiYmE0dW9of Gd4OjE1YTQ3NTg4YzA4NGQyNTE

Sugiyono. (2018). Metode Penelitian Kombinasi (mixed Methods). In Alfabet.

Tan, W.-L., Williams, J., \& Tan, T.-M. (2005). Defining the 'Social' in 'Social Entrepreneurship': Altruism and Entrepreneurship. The International Entrepreneurship and Management Journal, 1(3), 353-365. https://doi.org/10.1007/s11365-005-2600-x

Umar, H. (2005). Riset Pemasaran \& Perilaku Konsumen (Ketiga). PT Gramedia Pustaka Utama. https://books.google.co.id/books?id=471eLm2dtssC\&lpg=PP1\&ots=IoC07v9iKd\&dq=info\%3AD9 GVYEV9eU8J\%3Ascholar.google.com\&lr\&pg=PP1\#v=onepage\&q\&f=false

Undang-Undang No. 20 Tahun 2008, UU No. 20 Tahun 20081 (2008).

Waris, A. P. M. dan A. (2015). Effect of Training, Competence and Discipline on Employee Performance in Company (Case Study in PT. Asuransi Bangun Askrida). Procedia - Social and Behavioral Sciences. https://doi.org/10.1016/j.sbspro.2015.11.165

Waterhouse, L. (2006). Inadequate evidence for multiple intelligences, Mozart effect, and emotional intelligence theories. In Educational Psychologist. https://doi.org/10.1207/s15326985ep4104_5

Webb, K. S. (2012). Emotional Intelligence and Business Success. SSRN Electronic Journal, September. https://doi.org/10.2139/ssrn.1948065

Wijayanti, R., Suwandi-suwardi, J., Surakarta, U. M., \& Pos, T. (2012). Motivasi Kerja Terhadap Kinerja Karyawan. Jurnal Ekonomi Manajemen Sumber Daya, 13, 108-115.

Wirawan, D. M. S. A. M. M. S. (2014). KEPEMIMPINAN: Teori, Psikologi, Perilaku Organisasi, Aplikasi dan Penelitian (2nd ed.). PT RajaGrafindo Persada. http://www.rajagrafindo.co.id

Yıldız, S., Baştürk, F., \& Boz, İ. T. (2014). The Effect of Leadership and Innovativeness on Business Performance. Procedia - Social and Behavioral Sciences, 150, 785-793. https://doi.org/10.1016/j.sbspro.2014.09.064

Yuningsih, E., Gemina, D., \& Harini, S. (2018). The Effects of The Economics, Social, Environment, LayOut Of The City and Public Order Upon The Performance Of The Public Culinary Stalls. The Management Journal of Binaniaga. https://doi.org/10.33062/mjb.v1i02.17

Zaato, S. G., Ismail, M., Uthamaputhran, S., Owusu-Ansah, W., \& Owusu, J. (2020). The Influence of Entrepreneurial Orientation on SMEs Performance in Ghana: The Role of Social Capital and Government Support Policies. Jurnal Manajemen Dan Kewirausahaan, 22(2), 99-144. https://doi.org/10.1007/978-3-030-69221-6_96

Zain, S. M., Basri, N. E. A., Mahmood, N. A., Basri, H., Yaacob, M., \& Ahmad, M. (2013). Innovation in sustainable education and entrepreneurship through the UKM recycling center operations. International Education Studies, 6(6), 168-177. https://doi.org/10.5539/ies.v6n6p168 